УДК 378.016:[784:781.68]

DOI:

Лінь Янь, аспірант

Національного педагогічного університету імені М.П. Драгоманова, м. Київ

\title{
МЕТОДИКА ФОРМУВАННЯ ГОТОВНОСТІ МАЙБУТНІХ УЧИТЕЛІВ МУЗИКИ ДО ХУДОЖНЬО-ІНТЕРПРЕТАЦІЙНОЇ ДІЯЛЬНОСТІ
}

У статті розглянуто поетапну методику формування готовності майбутніх учителів музики до художньо-інтерпретаційної діяльності. Мета першого (установчо-інформаційного) етапу полягала у зацікавленні студентів художньо-інтерпретаційною діяльністю. Другий (діяльнісно-орієнтований) етап спрямовувався на збагачення студентів знаннями про професійну значущість вокального мистецтва, набуття відповідних знань, розвиток умінь і навичок, що визначають успішність художньо-інтерпретаційной діяльності. На третьому (творчо-самостійному) етапі вирімувались такі основні завдання: розширити $i$ збагатити художньо-виконавський тезаурус студентів; активізувати їх здатність до творчого самовираження у педагогічній і виконавській діяльності; забезпечити реалізачію набутого досвіду художньоінтерпретачійної діяльності в самостійній роботі.

Ключові слова: готовність; виконавство; вокальне мистецтво; діяльність; інтерпретація.

Jim. 5.

Lin Yan, Postgraduate Student Mykhaylo Drahomanov National Pedagogical University, Kyiv

\section{METHODOLOGY OF FORMATION OF READINESS OF FUTURE MUSIC TEACHERS FOR THE ARTISTIC AND INTERPRETIVE ACTIVITIES}

In the article the method of forming the readiness of future music teachers for artistic and interpretive activity is considered. Practical realization of the technique is possible by taking into account the following conditions: the students' development of the biophysical and orphoetic foundations of the vocal language; careful attitude to the literary text, his artistic-figurative content; the student's understanding of vocal-performing stylistics of a musical work; adaptation of students to concert performances. The purpose of the first (installation-information) phase was the interest of students in artistic and interpretive activities. Based on the personally oriented approach as a strategic direction of organizing artistic education, as well as on the principles of humanism, active informative influence, conscious and unconscious methods of cognition, this stage was aimed at solving the following tasks: outlining the main areas of vocal development of students for the experiment period; formation of the creative attitude of students to the profession of music teacher, the development of artistic interests and the desire to study vocal art; activating the emotional sphere on the basis of familiarization with different kinds of art for creating convincing artistic and performing interpretations; development of skills for the creative processing of musical material and music literature; development of dialogue skills, ability to express their point of view. The second (activity-oriented) stage aimed at enriching students with knowledge about the professional significance of vocal art, acquiring relevant knowledge, developing skills and skills that determine the success of artistic and interpretive activities, in particular: artistic reflection, ability to musical knowledge and vocal self-improvement. The realization of these tasks was based on the principles of variability, succession in vocal learning, imitation, communicative interaction, which correspond to active, functional, and personally oriented approaches, the main values of which are awareness of their own professional essence and readiness for artistic and interpretive activity. At the third (creative-independent) stage the following main tasks were solved: to expand and enrich the artistic and performing thesaurus of students; to intensify their ability to express themselves in pedagogical and performing activities; to ensure realization of the acquired experience of artistic and interpretive activity in independent work. The main methods of work on this were cognitive (discussion, explanation, commentary, analytical observation, the method of sketching works, the method of verbalizing the content of musical and artistic works, the thoughtful reading of musical works), creative (artistic presentation, joint reminder, commentary on video and audio material, free choice of tasks, analytical debates) and special (artistic guidance, artistic beliefs).

Keywords: readiness; performance; vocal art; an activity; interpretation.

П остановка проблеми. Реформування навчально-виховного процесу та підвищення його ефективності на мистецьких факультетах педагогічних закладах вищої освіти УкраїниіКитаю вимагає розроблення нових методів і прийомів навчання, що забезпечують формування готовності майбутніх учителів музики до художньо-інтерпретаційної діяльності. У наукових дослідженнях представлено різноманітні підходи до розв'язання даної проблеми.

Аналіз останніх досліджень. В історико- 


\section{МЕТОДИКА ФОРМУВАННЯ ГОТОВНОСТІ МАЙБУТНІХ УЧИТЕЛІВ МУЗИКИ ДОХУДОЖНЬО-ІНТЕРПРЕТАЦЙНОӤ ДІЯЛЬНОСТІ}

культурному контексті особливості художньоінтерпретаційної діяльності розглядались в роботах А. Алексєєва, Л. Д'ячкової, В. Москаленка, Т. Чередниченка та ін.; методичні аспекти даного виду діяльності розроблялись в роботах Л. Вовк, О. Ляшенко, Г. Падалки, Пан На Н. Шатайло та ін.; сучасні тенденції вокального розвитку майбутніх учителів музики представлено в роботах В. Бриліної, Л. Василенко, Н. Овчаренко, Л. Тоцької, Ю. Юцевича та ін. Соціальнопедагогічна та методична значущість означеної проблеми, недостатній рівень їі розробленості в теоретичному і методичному аспектах зумовило створення методики формування готовності майбутніх учителів музики до художньоінтерпретаційної діяльності в процесі вокального навчання.

Мета статті - представити основні етапи методики формування готовності майбутніх учителів музики до художньо-інтерпретаційної діяльності в процесі вокального навчання.

Виклад основного матеріалу. Модернізація сучасної мистецької освіти зумовлена зростанням вимог до фахової підготовки майбутніх учителів музики, складовою якої є готовність до художньоінтерпретаційної діяльності. Узагальнення даних констатувального експерименту засвідчило, що у вокальній підготовці майбутніх учителів музики недостатньо уваги приділяється формуванню готовності до художньо-інтерпретаційної діяльності. Ї̈̈ формування здійснюється здебільшого стихійно, про що свідчить нерівномірність у розвитку компонентів означеної якості, що зумовило пошук і розроблення експериментальної методики формування готовності майбутніх учителів музики до художньо-інтерпретаційної діяльності, заснованій на засадах особистісно орієнтованого, діяльнісного, функціонального, культуро-логічного та структурносеміотичного підходів, розроблених спеціальних принципах і педагогічних умовах.

Відповідно представленої методики, оволодіваючи вокальними знаннями, вміннями і навичками, студенти водночас засвоюють прийоми художньо-інтерпретаційної діяльності, що розширює діапазон їх практичного застосування в умовах загальноосвітньої школи. Методика реалізує ідею про те, що формування готовності до художньо-інтерпретаційної діяльності слід здійснювати через організацію цілеспрямованого управління процесом вокального навчання студентів із одночасним засвоєнням ними знань, навичок і вмінь.

Основою методики стала розроблена та обгрунтована структурно-функціональна модель формування готовності майбутніх учителів музики до художньо-інтерпретаційної діяльності, що включала мету, завдання, зміст, етапи, принципи, методи, педагогічні умови формування означеної якості.

Розроблена експериментальна методика формування готовності майбутніх учителів музики до художньо-інтерпретаційної діяльності грунтувалась на заальнонаукових (гуманізації, системності, співробітництва, активності, наочності) та спеціальних принципах (виконавського самоконтролю, виконавської новизни, виконавської рефлексії, виконавського артистизму), обгрунтованих нами у теоретичному розділі дослідження. Впровадження цих принципів у вокальну практику мистецьких факультетів вищих навчальних закладів України і Китаю вимагало створення відповідного середовища в умовах супідрядності групових, колективних та індивідуальних форм навчання, що реалізуються у ситуаціях діалогової взаємодії викладача і студента, художньо-інтерпретаційної спрямованості навчання у класі вокалу, активізації вокальновиконавських та творчих здібностей студентів [3].

Відзначимо, що практична реалізація методики формування готовності в майбутніх учителів музики до художньо-інтерпретаційної діяльності здійснювалась 3 урахуванням наступних умов: освоєння студентами біофізичних і орфоепічних основ вокальної мови; уважне ставлення до літературного тексту, його художньо-образного змісту; розуміння студентами вокальновиконавської стилістики музичного твору; адаптованість студентів до концертних виступів.

Впровадження методики формування готовності майбутніх учителів музики до художньо-інтерпретаційної діяльності здійснювалось у три етапи (установчо-інформаційний діяльнісноорієнтований, творчо-самостійний), кожен з яких мав свою мету, завдання та власну структуру. Етапи було сплановано таким чином, аби на кожному з них відбувалось поступове формування усіх компонентів готовності майбутніх учителів музики до художньо-інтерпретаційної діяльності на основі вокального саморозвитку та самовдосконалення.

Метою першого (установчо-інформаційного) етапу було зацікавлення студентів художньоінтерпретаційною діяльністю як складовою їх вокального розвитку. Грунтуючись на особистісно орієнтованому підході як стратегічному напрямку організації мистецької освіти, а також на принципах гуманізму, активно-інформативного впливу, усвідомленого та неусвідомленого способів пізнання, цей етап спрямовувався на 


\section{МЕТОДИКА ФОРМУВАННЯ ГОТОВНОСТІ МАЙБУТНІХ УЧИТЕЛІВ МУЗИКИ ДОХУДОЖНЬО-ІНТЕРПРЕТАЦЙНОЇ ДІЯЛЬНОСТІ}

вирішення таких завдань: окреслення основних напрямів вокального розвитку студентів на період експерименту; формування творчого ставлення студентів до професії вчитель музики, розвиток мистецьких інтересів та бажання вивчати вокальне мистецтво; активізація емоційної сфери на основі ознайомлення 3 різними видами мистецтва для створення переконливої виконавської інтерпретації; розвиток умінь творчо опрацьовувати музичний матеріал та музикознавчу літературу; розвиток навичок діалогового спілкування, вміння висловлювати свою точку зору.

Для вирішення поставлених завдань у ході установчо-інформаційного етапу використовувались такі методи (заохочення, схвалення, переконання, взаємодопомоги, наслідування відомої особистості, символічної винагороди дій студентів) і форми роботи (консультації, що спрямовувались на усвідомлення особистісного смислу музично-педагогічної професії, індивідуальні та групові заняття ).

Перший етап було розпочато з бесіди, що стосувалась допомоги в організації студентами власної навчальної діяльності, адаптації до умов закладу вищої освіти та вироблення у студентів “вчительського образу”. Адже, від того, яку установку буде сформовано у них на першому курсі, залежатиме процес їх становлення як педагога-музиканта так і виконавця-вокаліста протягом навчання у вищому педагогічному навчальному закладі [4].

Наступною була проведена лекція "Художньоінтерпретаційна діяльність - складова вокальної підготовки студентів". На лекції акцентувалась увага на специфіці художньо-інтерпретаційної діяльності в загальноосвітній школі, на вікових особливостях учнів різного шкільного віку, на важливість комунікативних та вокальновиконавських умінь для успішного здійснення художньо-інтерпретаційної діяльності [3; 5]. Варто зазначити, що теоретичний матеріал лекції ілюструвався музичними, літературними та художніми зразками, використовувався проблемний підхід до висвітлення питань.

В умовах дефіциту навчального часу доцільним виявилось надання студентам домашніх завдань, спрямованих на вивчення наукової літератури, присвяченій професії “вчитель музики". "Екскурс" до історії музичної освіти познайомив студентів 3 такими видатними українськими педагогами як В.Верховинець і М.Леонтович та інші які зробили вагомий внесок в теорію та методику музичної освіти, започаткували введення художньо-інтерпретаційної діяльності у роботі з дітьми. Ми прагнули, щоб образ цих вчителів став для студентів професійним еталоном, що визначає стиль їх життя та поведінки.

Підсумовуючи результати першого етапу, слід зазначити, що завдяки проведеній роботі було визначено основні напрями вокального розвитку студентів, значно підвищено рівень навчальної мотивації першокурсників, сформовано позитивне ставлення до художньо-інтерпретаційної діяльності та перспективне бачення студентом процесу власного вокального зростання, вміння його планувати. Протягом етапу було отримано узагальнену та об'єктивну характеристику кожного студента, що уможливлювало подальший доцільний добір методів і форм роботи.

Домінантою другого (діяльнісно-орієнтованого) етапу стало збагачення студентів знаннями про професійну значущість вокального мистецтва, набуття відповідних знань, розвиток умінь і навичок, що визначають успішність художньоінтерпретаційної діяльності, зокрема: мистецьку рефлексію, здатність до музичного пізнання та вокального самовдосконалення. Реалізація цих завдань грунтувалась на принципах варіативності, наступності у вокальному навчанні, наслідування, комунікативної взаємодії, які відповідають діяльнісному, функціональному та особистісно орієнтованого підходам, головними цінностями яких є усвідомлення власної професійної сутності і готовність до художньо-інтерпретаційної діяльності. Організація діяльнісно-орієнтованого етапу відбувалась 3 урахуванням педагогічних умов: опори на життєвий і художній досвід студентів та досягнення діалогових засад взаємодії викладача і студента в процесі художньо-інтерпретаційної діяльності.

Важливою частиною експерименту на даному етапі стало оволодіння студентами алгоритмом художньо-інтерпретаційної діяльності [1;2; 5]. Для цього їм було запропоновано виконати наступне завдання: спираючись на сучасні дослідження проблеми художньо-інтерпретаційної діяльності, визначити та обгрунтувати основні їі етапи. При обговоренні питання студенти експериментальної групи висловились про необхідність оволодіння вміннями художньо-інтерпретаційної діяльності для успішної роботи в загальноосвітній школі. 3 цією метою вони вивчали праці Є. Гуренка, В. Москаленка, Г. Падалки, В. Чередниченка та ін. Опрацювання науковоїлітератури характеризувалось розбіжністю поглядів респондентів на особливості та специфіку художньо-інтерпретаційної діяльності в загальноосвітній школі. Характерними висловлюваннями були такі: “першим етапом $\epsilon$ 


\section{МЕТОДИКА ФОРМУВАННЯ ГОТОВНОСТІ МАЙБУТНІХ УЧИТЕЛІВ МУЗИКИ ДОХУДОЖНЬО-ІНТЕРПРЕТАЦИЙНОӤ ДІЯЛЬНОСТІ}

сприйняття музики”, “художньо-інтерпретаційна діяльність вимагає поєднання теоретичних знань і практичних умінь”, “відображення ідеї вокального твору залежить від виконавського досвіду”, “осмислення логіки і структури твору сприяє успішності художньо-інтерпретаційної діяльності”, “особливістю художньої інтерпретації вокального твору для дітей $є$ його доступність’. Такі висловлювання свідчили про продуктивний напрямок у засвоєнні майбутніми вчителями основ художньо-інтерпретаційної діяльності.

Практичне оволодіння студентами алгоритмом художньо-інтерпретаційної діяльності здійснювалось в процесі виконання студентами низки аналітичнопізнавальних завдань. Перше завдання стосувалось виявлення “тематичного ланцюжка" у творах різних видів мистецтва, що об'єднані спільним сюжетом (наприклад: поезія - музика живопис). Так студентам пропонувалось виявити спільність сюжетного підгрунтя наступних творів:

1. Лю Сунн на слова Фань Сяопинь “Пташки співають на повітрі" (романс), Л. Костенко “Про природу” (поезія), Ні Цзань “Дерева, долини і гори" (живопис).

2. Ло Чжунжун "Перейти річку за лотосом", Л. Косенко “Напитись голосутвого” (поезія), І. Левітан “Весна. Велика вода".

3. Л.Дичко на слова I Франка “Журавлі" (романс), Л. Косенко “Про мрії” (поезія), Ці Байші “Осіння цикада на квітках лапіни” (живопис).

Використання методів аналогій та порівняння було спрямоване на розвиток у студентів уміння бачити в подібних творах специфічні особливості та виокремлення спільних рис в різних та подібних за сюжетом творах.

Ознайомлення 3 низкою творів китайської культури відбувалось на індивідуально-груповому занятті в класі вокалу. Цей вид роботи зацікавив більше українських студентів, адже ця культура $є$ мало відомою для них. У романсі Лю Сунн на слова Фань Сяопинь "Птахи співають на вітрі" студенти відзначили специфічні інтонаційні оберти, гармонічні звороти, розставлення акцентів, що відображає специфічну китайську мову: музика більш поривчаста, мелодія загострена і нагадує не пісню, а схвильовану людську мову. Завершується твір тією ж мелодією, що і розпочинався. Необхідно відзначити, що у живописі Ні Цзань “Дерева, долини і гори”, який за манерою письма мало подібний до європейського мистецтва, автор зумів відтворити своєрідність цієї пори року. У поезії, Л.Костенко, на думку студентів з Китаю, поетеса наче милується, захоплюється власними мріями, вона пройнята настроєм смутку, спокійного роздуму.
На думку майбутніх фахівців, взаємодія поезії та музики створює нову музично-поетичну якість, унаслідок чого збагачуються уявлення про специфіку художньо-образного відображення світу, про закономірності музики, а також формується готовність до художньо-інтерпретаційної діяльності.

Третій (творчо-самостійний) етап мав за мету оволодіння студентами способами самостійної творчої діяльності, удосконалення організаційних, комунікативних, оцінювальних та виконавських умінь (інтерпретаційних, імпровізаційних) i спрямовання їх у практичну площину, де активізувалися всі компоненти готовності до художньо-інтерпретаційної діяльності.

Відповідно до поставленої мети було визначено такі основні завдання: розширити і збагатити художньо-виконавський тезаурус студентів; активізувати їх здатність до творчого самовираження у педагогічній і виконавській діяльності; забезпечити реалізацію набутого досвіду художньо-інтерпретаційної діяльності в самостійній роботі. Вирішення цих завдань здійснювалось на основі принципів: творчої активності, виконавської новизни, виконавської рефлексії, виконавсього артистизму, інтересу до художньо-інтерпретаційної діяльності, які реалізувалися в ситуаціях творчої взаємодії, художньо-педагогічної спрямованості вокального навчання, активного використання комунікативних та творчих здібностей студентів. Реалізація поставлених завдань забезпечувалась такими педагогічними умовами: розуміння вокальновиконавської стилістики вокальних творів, адаптованості студентів до концертних виступів.

Одним із завдань цього етапу стало порівняння декількох інтерпретаційних версій. Для прикладу було обрано записи арії Клеопатри "Da tempeste" iз опери “Юлій Цезар в Сгипті”, яка є прикрасою виконавського репертуару будь-якої оперної співачки. Серед сучасних відзначимо Юлію Лежнєву, Наталі Дессей, Чечілію Бартолі та українську співачку О. Пасічник які неперевершено виконують цей твір, підкреслюючи унікальність свого голосу особливими технічними прийомами. Після прослуховування студенти відзначили: у виконанні Юлія Лежнєвої-технічну майстерність, у Чечілії Бартолі - гнучкість гортані, чим дивує та захоплює слухачів, у Наталі Дессей невимушеність, що досягається правильним диханням, виконання О. Пасічник приваблює красивим тембром та мелодією, прикрашеною великою кількістю різноманітних колоратур.

Надаючи великого значення прийому порівняння виконавських версій, відзначимо, що 
при виконанні барокової музики кожен студент може проявити свої вокальні можливості за допомогою прикрас, які можна імпровізувати. Вивчення цих арій сприяє формуванню технічних навичок майбутнього вчителя музики, як от: ведення звуку, вирівнювання регістрів за допомогою зручної мелодії, “низьке” дихання, висока позиція звуковидобування. Також вони вдосконалюють уміння співати на різних мовах: французькій, італійській, німецькій, англійській, латині.

Висновки. Підсумовуючи сказане наголосимо, що в результаті цілеспрямованого впровадження методики формування готовності майбутніх учителів музики до художньо-інтерпретаційної діяльності, що включала як традиційні форми і методи роботи, так і спеціальні, характерні для практики вокального навчання ми отримали значне підвищення рівня сформованості означеної якості в студентів експериментальної групи. Запропонована методика дозволила реалізувати вокальні, творчі, комунікативні можливості студентів за рахунок участі у бесідах та дискусіях; підвищити виконавську мотивацію; визначити провідні установки їх вокального навчання. Відповідно, художньо-інтерпретаційна діяльність майбутніх учителів музики вийшла за межі вокального класу, набула особистісного сенсу і спрямованості на майбутню музичнопедагогічну діяльність.

Подальшого наукового дослідження потребує виявлення шляхів реалізації художньоінтерпретаційної діяльності в умовах загальноосвітньої школи.

\section{ЛІТЕРАТУРА}

1. Москаленко В.Г. Аналіз у ракурсі музичної інтерпретації. Часопис Національної музичної академії України імені П. І. Чайковського. № 1(1). Київ, 2008. С. 106-111.

2. Падалка Г. М. (2004) Художньо-педагогічна інтерпретація музики в структурі професійної підготовки музиканта-педагога. Теорія $i$ методика мистецької освіти. Київ, 2004, Вип.5. C.3-9.
3. Пан На Методика роботи над виконавською інтерпретацією у процесі вокальної підготовки педагогів-музикантів України та Китаю. Автореф. канд. пед. наук. Київ, 2013. 20 с.

4. Овчаренко Н.А. Теоретико-методологічні засади професійної підготовки майбутніх учителів музичного мистецтва до вокально-педагогічної діяльності. Атореф. докт. пед. наук. Київ. 40 с.

5. Чередниченко Т. Композиция и интерпретация: три среза проблемы. Музыкальное исполнительство и современность.Вып.1.Москва, 1988. с.43-86.

\section{REFERENCES}

1. Moskalenko, V.H. (2008). Analiz u rakursi muzychnoi interpretatsii [Analysis in terms of musical interpretation]. Journal of the Petro Tchaykovskiy National Academy of Music of Ukraine. No. 1(1). Kyiv. pp.106-111. [in Ukrainian].

2. Padalka, H. M. (2004). Khudozhnopedahohichna interpretatsiia muzyky v strukturi profesiinoi pidhotovky muzykanta-pedahoha [Artistic and pedagogical interpretation of music in the structure of professional training musician-teacher]. Theory and methodology of art education. Vol.5, Kyiv. pp.3-9. [in Ukrainian].

3. Pan $\mathrm{Na}$ (2013). Metodyka roboty nad vykonavskoiu interpretatsiieiu u protsesi vokalnoi pidhotovky pedahohiv-muzykantiv Ukrainy ta Kytaiu [Method of work on performing interpretation in the process of vocal training of musicians-musicians from Ukraine and China]. Extended abstract of candidate's thesis. Kyiv. 20 p. [in Ukrainian].

4. Ovcharenko, N.A. (2015). Teoretykometodolohichni zasady profesiinoi pidhotovky maibutnikh uchyteliv muzychnoho mystetstva do vokalno-pedahohichnoi diialnosti [Theoretical and methodological principles of professional training of future teachers of musical art to vocal and pedagogical activity]. Extended abstract of Doctor's thesis. $40 \mathrm{p}$. [in Ukrainian].

5. Cherednychenko, T. (1988). Kompozitsiya i interpretatsiya: tri sreza problemy [Composition and interpretation: three sections of the problem]. Musical performance and modernity. Vol.1. Moscov. pp.4386. [in Russian].

Стаття надійшла до редакції 27.06.2019

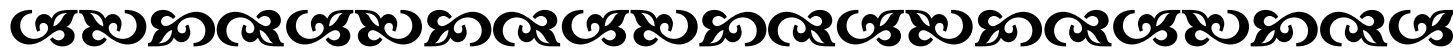

"Розвинені почуття, висоқа емоиійна қультура - ие, образно қажучи, абсолютний музичний слух моральної вихованності".

Василь Сухомлинсъкий український педагог, публіиист, письменник, поет

\section{G58080.20580}

